\title{
Trade Flow Estimation Between Russia and European Union Countries per Agricultural Commodity Group
}

\author{
Stanislava KONTSEVAYA ${ }^{1, *}$, Aleksander METLYAHIN ${ }^{2}$, Lubos SMUTKA ${ }^{3}$ and Alina \\ DANILOWSKA 4
}

1 Russian Timiryazev State Agrarian University, Moscow, Russia; s.konsevaya@mail.ru

2 Vologda State University, Vologda, Russia; a.metlyahin@mail.ru

3 Czech University of Life Sciences, Prague, Czech Republic; smutka@pef.czu.cz

4 Warsaw University of Life Sciences-SGGW, Warsaw, Poland; alina_danilowska@sggw.pl

* Correspondence: s.konsevaya@mail.ru

\begin{abstract}
All countries in the world are involved into international trade so it is crucially to understand economical patterns of interrelations between countries. This research is aimed to estimate current condition of international agricultural trade between Russia and EU countries for the period of 2000-2017. Import and export trade flows were estimated with the gravity model for specific groups of products. Impact of such variables as gross domestic product (GDP), the distance between countries, common border, language and history on trade flow value was also estimated. Impact of Russian import ban was also studied in the article. Obtained results of 48 regressions were subdivided into 3 groups for import and 4 groups for export by means of the cluster analysis. The classical gravity model works for meat, fruits and cereals, and this fact can be proved by existence of dependency between distance and GDP of trade partners. However, influencing factors for other groups of products are common language and border. The import ban variable influences each group of the agricultural products exported from Europe to Russia and partly extends its influence on the imported products. Hence, impact of import ban is much stronger than it was declared earlier.
\end{abstract}

Keywords: gravity model; Russian import ban; agriculture; trade

JEL Classification: Q1; F1; F510

\section{Introduction}

In the modern condition of the world international trade has quite important role and almost each country is involved into this game. Hence, it is of crucial importance to know every trick in the book of trade mechanisms and estimate impact of such different factors as bans or export specialization in definite kinds of products.

The conventional tool for estimation of trade flows between countries is the gravity model. It was firstly suggested by Timbergen (1962) and further Anderson (1979) put finishing touches on this model. He suggested that the key criteria in choosing a supplier or a service are a distance and a delivery price. An ideal supplier is the one which can deliver the product of required quality at lowest price in time. Anderson suggested specification of the model in the way that each country was specialized in production of one (or some) products. In other words, he confirms that the gravity model can be utilized for some single industry (product).

Traditionally the gravity model (Koo 1994) utilizes a panel data to take into account implicit characteristics and temporal effects. In his work "Meat trade polices" he generated the model for the specific product group.

The other question appearing when implementing such model is the choice of the model type that is the pooled ordinary least square (OLS) or the fixed ordinary least square or random ordinary least square. Recently some scientists utilized pooled OLS (Kankge, 2006) though it does not meet BLUE requirements. Fixed or random effect models help solving problem with missing variables. The main difference between the fixed effect OLS and random effect OLS is that changes between objects are 
random and they are not related to the explanatory variables in the model. It was random effect model which was utilized in this research as it omitted all dummy variables.

The research is aimed to estimate current condition of international agricultural trade between Russia and EU countries. Research objective is to generate the regression model using the gravity model approach for the particular group of agricultural products and find some regularities using cluster analysis.

\section{Methodology}

The idea of utilization of gravity in economics is based upon Newton's universal gravitation law stating that the more mass and the less distance between objects the more magnitude of the attraction force between them. Resting upon this approach Timbergen (1962) created the gravity model in the international trade.

$$
\ln X_{i j}=\underbrace{\ln G}_{a_{0} \equiv \text { constant }}+\underbrace{a_{1} \ln M_{i}+a_{2} \ln M_{j}}_{\text {economic attractors }}+\underbrace{a_{3} \phi_{i j}+a_{4} N_{i j}}_{\text {distance }}+\underbrace{a_{5} V_{i j}}_{\text {policy }}+\underbrace{\varepsilon_{i j}}_{\text {iid }}
$$

where:

Xij - the size of trade flow between two countries

$\mathrm{Mj}$ - the amount of exports from the country $i$ to the country $j$

Since that time the gravity model was studied and modified lots of times. For instance, Assem (2005) in his research "Agricultural exports in Egypt" offers an additional variable "Regional trade agreement". Keith (2006) suggests a dummy variable "Common border".

In this research the specification of the gravity model is the following:

$$
F(\text { agriculturaltradeflow })=\operatorname{Imp}_{i}, \operatorname{Exp}_{i}, G D P_{i}, G D P_{r u}, D_{i}, B_{i}, L_{i}, H_{i}, S_{i}, B N_{i}
$$

Impi- Import trade flow of agricultural products from some EU country to Russia

Exp $_{i}$ - Export trade flow of agricultural products into some EU country from Russia

GDP - GDP (ppp) of EU country, million USD

GDPru - GDP (ppp) of Russia, million USD

$\mathrm{D}_{\mathrm{i}}$ - the variable designating the distance between capitals of EU countries and Moscow or St.

Petersburg

$\mathrm{B}_{\mathrm{i}}$ - the dummy variable designating existence of common border between countries

$\mathrm{Li}_{\mathrm{i}}$ - the dummy variable designating existence of common language for work

$\mathrm{H}_{\mathrm{i}}-$ Existence of active relations for the last 100 years

$\mathrm{S}_{\mathrm{i}}$ - Existence of a sea port on the territory of each country

$\mathrm{BN}_{\mathrm{i}}$-Russian import ban

The variables of import/export trade flow and the distance between countries are taken from Tinbergen's model (Eq. 1). Some dummy models impacting import/export of agricultural products are also included into the model. Existence of common border, common language for work and active historical relations in EU country facilitate external trade. Existence of a seaport significantly cheapens price of good delivery between countries. The variable ban decreases trade volume between EU countries and Russia.

These calculations were made with the data about import/export between EU countries and Russia from Un cometrade database. The selection comprises 29 countries - 28 European countries and Russia. Import and export was subdivided into 24 agricultural items. Thus, the analysis included 24 groups of agricultural products for the period of 18 years since 2000 till 2017. To eliminate inflation impact trade flow data was indexed by agricultural producer price index from FAOSTAT. The data of GDP volume for the total period were taken in the constant prices from WTO site. The calculations were performed in STATA 15 software. The Table 1 presents the data of descriptive statistics. 
Table 1. Descriptive statistics for the gravity models.

\begin{tabular}{lccccc}
\hline \multicolumn{1}{c}{ Variable } & Obs & Mean & Std. Dev. & Min & Max \\
\hline Import thou. USD & 12,096 & $7,989,822$ & $2.46 \mathrm{e}+07$ & 0 & $4.39 \mathrm{e}+08$ \\
Export thou. USD & 12,096 & $1,610,126$ & $1.13 \mathrm{e}+07$ & 0 & $6.44 \mathrm{e}+08$ \\
GDP EU mln. USD & 12,096 & 606,072 & $859,280.8$ & 9,605 & $3,740,232$ \\
GDP RU mln. USD & 12,096 & $3,094,072$ & $550,526.6$ & $2,059,806$ & $3,693,841$ \\
Distance km. & 12,096 & $1,856.32$ & 854.5 & 300 & 3,907 \\
Boarder & 12,096 & 0.1 & 0.3 & 0 & 1 \\
Language & 12,096 & 0.3 & 0.4 & 0 & 1 \\
History & 12,096 & 0.2 & 0.4 & 0 & 1 \\
Sea port & 12,096 & 0.8 & 0.3 & 0 & 1 \\
Ban & 12,096 & 0.2 & 0.4 & 0 & 1 \\
\hline
\end{tabular}

Source: Un cometrade, own calculation.

The data was tested by BLUE and some specifications for the model were applied. These specifications are the ordinary least square, the panel data model, the generalized least square, the random and fixed effect model. In order to find the most suitable model the series of such tests as the Ramsey test, the Breush-Pagan test, the White test, the Haussmann specification test and the Breush Pagan LM test for random effects was made. Finally the model with panel data generalized least square model with random effect was considered the most suitable one. The variables import, export and distance were taken logs. Final formula of the gravity model is the following (Equation 3).

$$
F(\text { tradeflowper commodity })=\operatorname{LnImp}_{i}, \ln E_{x} p_{i}, \ln G D P_{i}, \ln G D P_{r u}, \ln D_{i}, B_{i}, L_{i}, H_{i}, S_{i}, B N_{i}
$$

This model was utilized for each of 24 groups of imported and exported products. A set of specific variables was assigned to each group of products. Further the results of modeling were subjected to the cluster analysis by Ward's method (Ward 1963).

\section{Results}

\subsection{Current condition of agricultural trade between Russia and the Eropean Union. Impact of import ban}

Import of agricultural products exceeds export by several times in modern condition of international trade in Russia. Though, as it is presented on the Fig. 1, there is a trend of reduction of import and increase of export but this gap is still big.

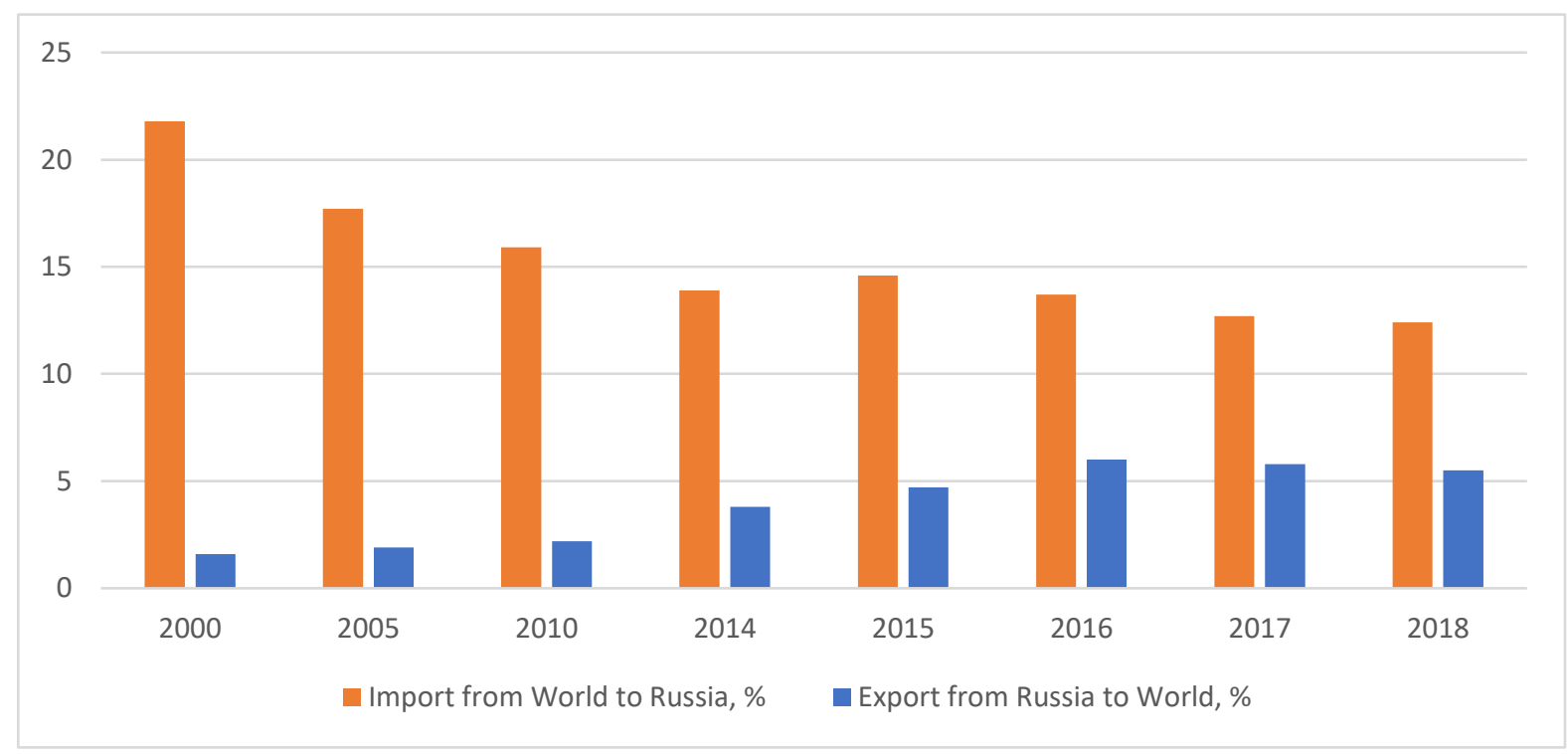

Figure 1. Share of agricultural products in International trade in Russia. 
The most imported products for 18 years are machinery, equipment and transport in Russia. In 2018 the share of this import was $47.3 \%$. The share of mineral products export was more than $70 \%$ as it was expected in Russia. In 2018 this share was $64.8 \%$.

The EU together with China, Belarus and Brazil was the key trade partner of Russia. The share of imported agricultural products in Russia from the EU was 37\% from the total import of agricultural products. The most demanded products according to Fig. 1 are meat and beverages. The data was presented in constant prices for 18 years. Imported products from Russia are far less and they include fish (3), cereals (10), and animal, vegetable fats and oils (15).

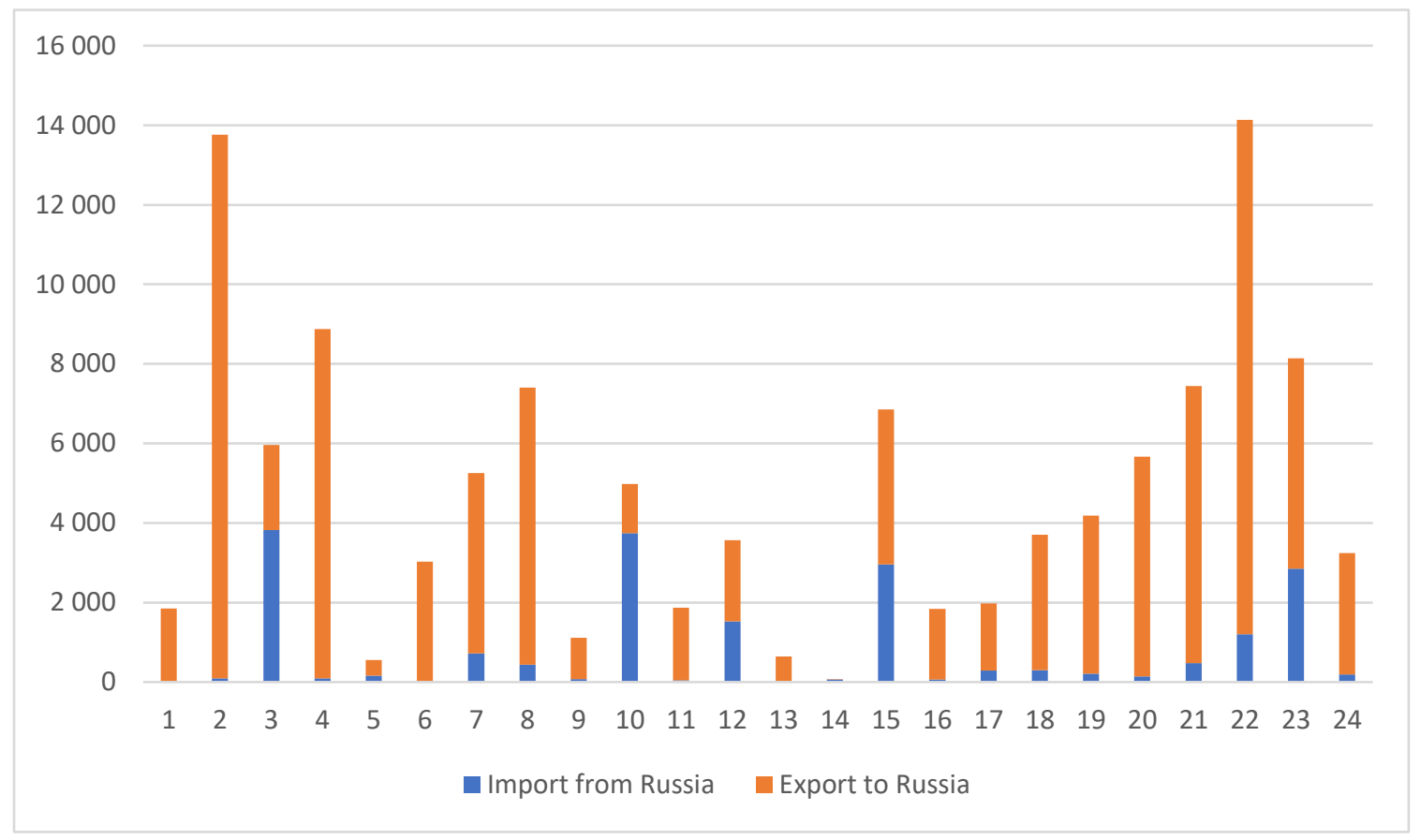

Figure 2. Export and import of agricultural products for the period 2000-2017, constant price, bill. USD.

Where: 1-Live animals; 2-Meat and edible meat offal; 3-Fish, crustaceans, molluscs, aquatic invertebrates etc; 4-Dairy products, eggs, honey, edible animal product etc; 5-Products of animal origin; 6-Live trees, plants, bulbs, roots, cut flowers etc; 7-Edible vegetables and certain roots and tubers; 8Edible fruit, nuts, peel of citrus fruit, melons; 9-Coffee, tea, mate and spices; 10-Cereals; 11-Milling products, malt, starches, inulin, wheat gluten; 12-Oil seed, oleaginous fruits, grain, seed, fruit, etc; 13Lac, gums, resins, vegetable saps and extracts; 14-Vegetable plaiting materials, vegetable products; 15 Animal,vegetable fats and oils, cleavage products, etc; 16-Meat, fish and seafood and food preparations; 17-Sugars and sugar confectionery; 18-Cocoa and cocoa preparations; 19-Cereal, flour, starch, milk preparations and products; 20-Vegetable, fruit, nut, other food preparations; 21Miscellaneous edible preparations; 22-Beverages, spirits and vinegar

In 2014 Russia imposed food ban (embargo) for certain agricultural products against countries Canada, Australia, the European Union, the United States and Norway. Banned products are presented in the Table 2. Ban covered the most popular exported products in Russia from the EU.

Table 2. The structure of the banned imported products in 2013.

\begin{tabular}{|c|c|c|c|c|c|c|c|c|c|c|c|c|}
\hline \multirow{2}{*}{$\begin{array}{c}\text { Commodity } \\
\text { code }\end{array}$} & \multicolumn{2}{|c|}{ Canada } & \multicolumn{2}{|c|}{$\begin{array}{l}\text { Australia } \\
\text { mill. }\end{array}$} & \multicolumn{2}{|c|}{$\begin{array}{l}\text { Norway } \\
\text { mill. }\end{array}$} & \multicolumn{2}{|c|}{$\begin{array}{l}\text { USA } \\
\text { mill. }\end{array}$} & \multicolumn{2}{|c|}{$\begin{array}{l}\text { EU members } \\
\text { mill. }\end{array}$} & \multicolumn{2}{|c|}{$\begin{array}{l}\text { Total } \\
\text { mill. }\end{array}$} \\
\hline & USD & $\%$ & USD & $\%$ & USD & $\%$ & USD & $\%$ & USD & $\%$ & USD & $\%$ \\
\hline Meat (2) & 255 & 68.14 & 202 & 69.10 & 0 & 0.00 & 323 & 40.70 & 2,138 & 21.89 & 918 & 23.65 \\
\hline Fish & 106 & 28.27 & 0 & 0.17 & 1,106 & 99.55 & 81 & 10.24 & 209 & 2.14 & 1,502 & 12.17 \\
\hline Dairy (4) & 6 & 1.68 & 75 & 25.66 & 4 & 0.39 & 17 & 2.16 & 1,946 & 19.93 & 2,049 & 16.61 \\
\hline
\end{tabular}




\begin{tabular}{ccccccccccccc} 
Vegetab. (7) & 3 & 0.74 & 0 & 0.02 & 0 & 0.01 & 6 & 0.80 & 1,017 & 10.41 & 1,026 & 8.32 \\
Fruits (8) & 3 & 0.69 & 9 & 2.96 & 0 & 0.00 & 223 & 28.02 & 1,688 & 17.28 & 1,922 & 15.57 \\
Food prep. & & & & & & & & & & & & \\
$(16.19 .20 .21)$ & 2 & 0.46 & 6 & 2.09 & 1 & 0.06 & 144 & 18.08 & 2,769 & 28.36 & 2,922 & 23.68 \\
Total & 374 & 100 & 292 & 100 & 1,111 & 100 & 795 & 100 & 9766 & 100 & 12,338 & 100 \\
\hline
\end{tabular}

Smutka (2016) in his article suggested that Russian import ban was aimed to support Russian agriculture and remove competitors from the internal Russian market. This hypothesis is proved by the data from the Fig. 3. The share of imported products in Russian food malls was significantly decreased by comparison with the period before ban. Russian agricultural manufacturers successfully produce agricultural products and deliver them on internal market.

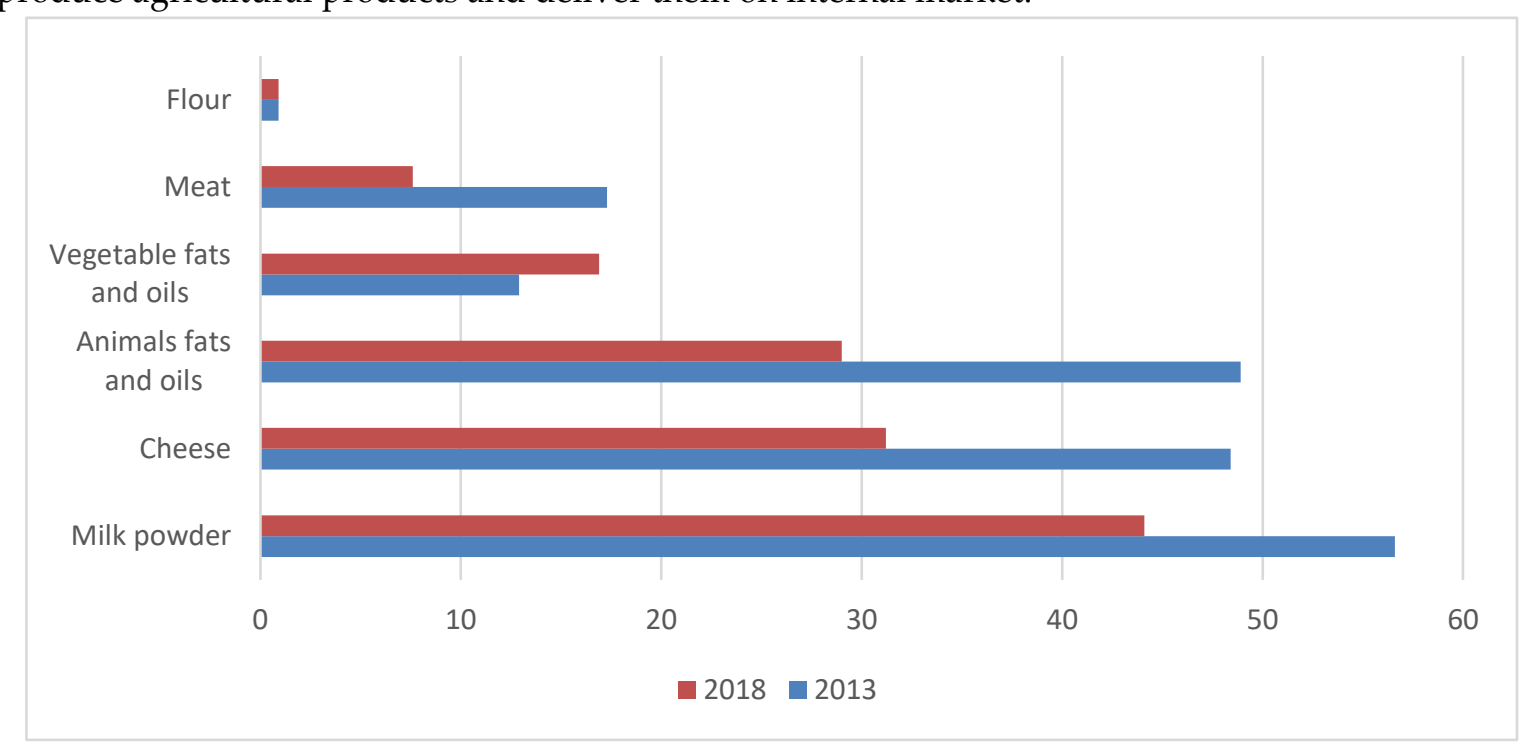

Figure 3. The share of imported goods in the Russian food stores 2013-2018.

The share of imported cheeses in Russia reduced from 50\% in 2013 to 30\% in 2018 (Fig.3), though these values do not reveal one important characteristic that is quality of the local products. The example of replacement of foreign cheese was presented in the article of Mirzobobo (2018) who investigated tastes of Russians. Russian customers do not consider Russian cheese dangerous for health but prefer more expensive European kinds of cheese in case of having financial abilities.

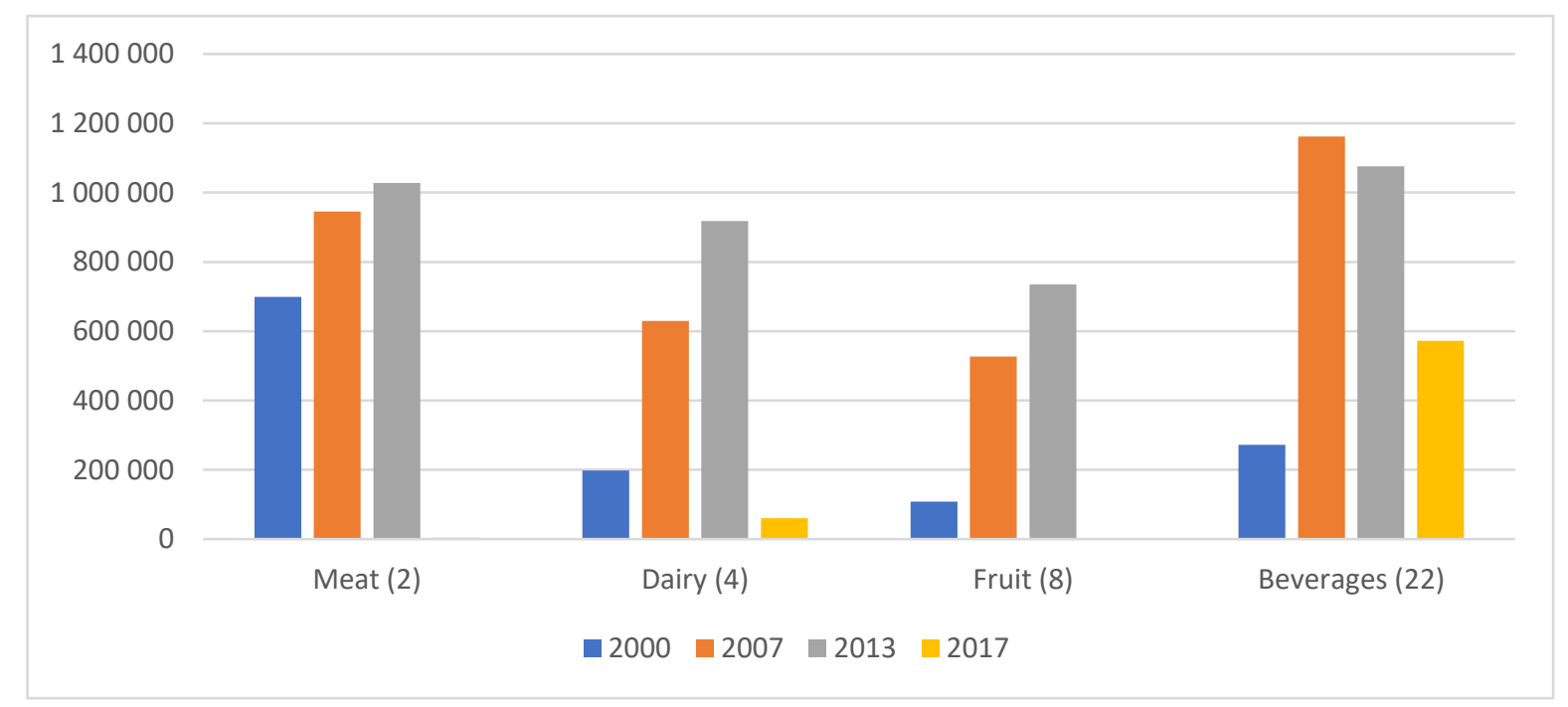

Figure 4. Main products exported to Russia from EU, 2000-2017, million USD. 
The most popular products from the EU in Russia are presented in Fig. 4. Export of all products was obviously decreased after 2013 and in 2017 even the group Beverages suffered from decrease though it was not banned officially. In other words the Fig. 4 presents impact of ban on exported agricultural products totally and not only on specific groups of products. This impact will be also proved by the regression model below.

\subsection{The regression analysis for paticular group of products using gravity model approach}

The article includes the regression analysis of the model with panel data generalized least square with random effect for each group of imported and exported products. So evaluation comprises 48 regression models made with formula 3. Evaluation comprises 48 regression models made with the formula 3. Each product type was checked using 5 types of the regression models. The best suitable model for each of 24 product was chosen using comparison test Breush - Pagan. First and second OLS models have serious problem with heteroskedasticity and do no fulfil BLUE assumption, even with the robust method. Example of calculation for dairy products is in the Table 3.

Table 3. Five types of regression models for dairy products exported to Russia from the EU.

\begin{tabular}{lcc|c|cc}
\hline Variables & OLS & $\begin{array}{c}\text { 2nd } \\
\text { OLS ln }\end{array}$ & $\begin{array}{c}\text { 3th Gravity } \\
\text { panel random } \\
\text { effects GLS }\end{array}$ & $\begin{array}{c}\text { 4th Gravity } \\
\text { panel random } \\
\text { effects ML }\end{array}$ & $\begin{array}{c}\text { 5th Gravity } \\
\text { panel fixed } \\
\text { effect }\end{array}$ \\
\hline Distance & $-11,263^{* * *}$ & $-1.166^{* * *}$ & -1.148 & $-1.169^{*}$ & Omitted \\
Border & $(1,920)$ & $(0.215)$ & $(0.809)$ & $(0.676)$ & \\
& 3.638 & $1.484^{* * *}$ & 1.555 & 1.616 & Omitted \\
Language & $(4.814)$ & $(0.428)$ & $(1.565)$ & $(1.310)$ & \\
& $-1.681^{* * *}$ & $-0.857^{* *}$ & -1.398 & -1.218 & Omitted \\
History & $(2.394)$ & $(0.342)$ & $(0.996)$ & $(0.853)$ & \\
& $3.420^{* * *}$ & $1.400^{* * *}$ & $2.071^{* *}$ & $1.883^{* *}$ & Omitted \\
Sea Port & $(3.861)$ & $(0.239)$ & $(0.980)$ & $(0.834)$ & \\
& $1.603^{* * *}$ & -0.299 & 0.00415 & -0.0894 & Omitted \\
GDP RU & $(2.417)$ & $(0.262)$ & $(0.895)$ & $(0.754)$ & \\
& $12.48^{* * *}$ & 3.151 & $2.544^{* * *}$ & $2.494^{* * *}$ & $4.111^{* * *}$ \\
GDP EU & $(2.620)$ & $(1.918)$ & $(0.430)$ & $(0.424)$ & $(0.603)$ \\
& $10.64^{* * *}$ & $0.953^{* * *}$ & $0.782^{* * *}$ & $0.875^{* * *}$ & $-2.392^{* * *}$ \\
Ban & $(2.373)$ & $(0.111)$ & $(0.298)$ & $(0.262)$ & $(0.922)$ \\
& $-2.313^{* * *}$ & $-1.498^{* * *}$ & $-1.708^{* * *}$ & $-1.709^{* * * *}$ & $-1.609^{* * *}$ \\
Constant & $(3.552)$ & $(0.420)$ & $(0.194)$ & $(0.194)$ & $(0.194)$ \\
& $-1.917^{* *}$ & 513.6 & $-24.91^{* * *}$ & $-25.11^{* * *}$ & $-15.84^{* *}$ \\
R-squared & $(7.447)$ & $(1,308)$ & $(8.551)$ & $(7.856)$ & $(7.760)$ \\
\hline Stan & 0.444 & 0.482 & 0.682 & - & 0.205 \\
\hline
\end{tabular}

Standard errors in parentheses ${ }^{* * *} \mathrm{p}<0.01,{ }^{* *} \mathrm{p}<0.05,{ }^{*} \mathrm{p}<0.1$

According to the Table 3, dairy products, exported to Russia, are influenced by GDP volume, Russian ban and availability of common history. The last brings positive effect to the trade flow, and ban logically shows negative effect.

Thereby, for analyzing data receiving from 48 regression models ( 24 for export and 24 for import), it was decided to group results of regression using the cluster analysis. Additional argument for the cluster analysis is that showing all regression results takes many pages. The cluster analysis allows observation of main trends of significant variables for imported and exported agricultural products.

The classical gravity model works for meat, fruits and cereals can be proved by existence of dependency between distance and GDP of trade partners. However, influencing factors for other groups of products are common language for office work and common border.

The results of the cluster analysis are presented in Fig.5. The groups were made by the indexes of the models obtained in the result of the regression analysis for each product. 

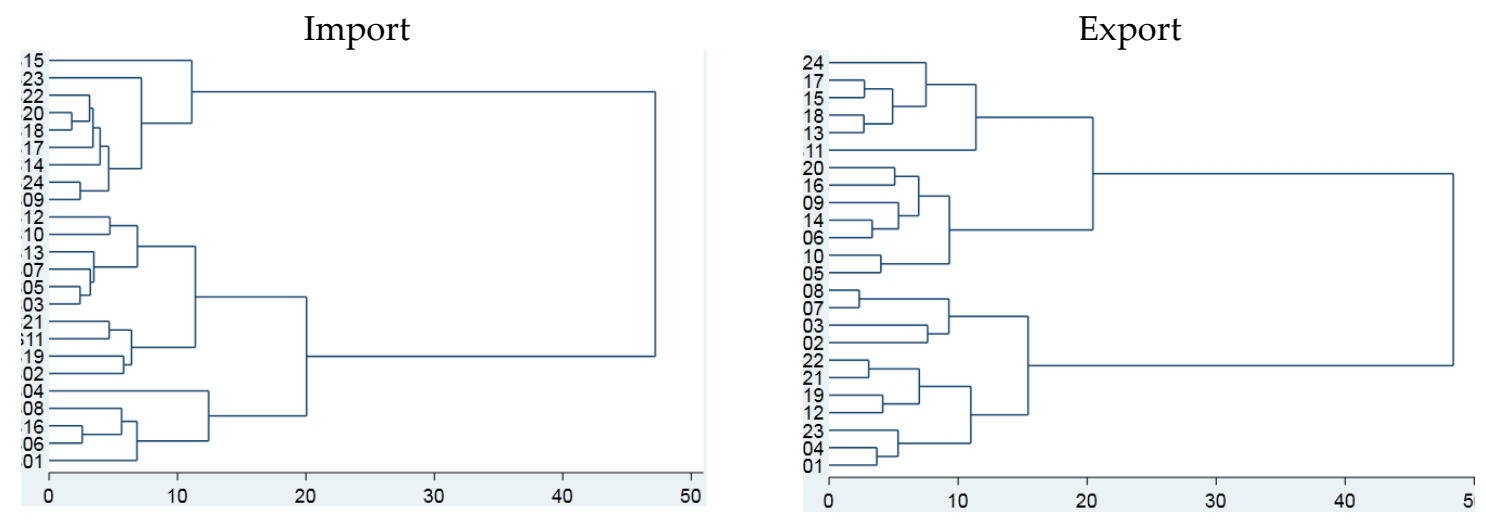

Figure 5. Dendrogramm based on Ward'smethods.

The structure Import includes 3 groups of clusters and the structure Export - 4 groups.

The variable "Import ban" is significant for all groups of exported products in Russia and imported from Russia. In other words, import ban influences stronger than it was expected earlier.

To summarize, different significant variables influence different type of agricultural products. Dependence between trade flow, GDP and distance does not suit for each type. Availability of common language and common boarder is more important than distance between countries for some commodities.

\section{Discussion}

The type and specification of the econometric model is subject of discussion. In this article the gravity model approach was implemented for evaluation of influence of Russian import ban and such indexes as common border, common language, sea port availability and common history. Previously other researches (Dascal 2002; Ferrantino 2006) showed good results of implementation of the gravity model approach. However, Babula (2005) investigated impact of non-tariff measures on wheat in the USA and suggested the vector autoregression model which provided more reliable evaluation. This approach provides more opportunities for future researches and it will be utilized for evaluation of temporal effects of Russian import ban on international trade of agricultural products.

Acknowledgments: This paper is supported by a grant of National Agency for Agricultural Research (NAZV). The project title is "Dualita v českémzemědělství: výhodanebonevýhoda pro zemědělstvínovégenerace?" (QK1920398).

\section{References}

Anderson E. James. 1979.Theoretical foundation for the gravity equation. American Economic Review: 69(1), 106116.

Assem A. Hatabm.2005. Determinants of Egyptian agricultural exports: a gravity model approach. Modern Economy: 3(1), 134-143. https://doi.org/10.4236/me.2010.13015

Babula Ronald. 2005. Using directed acyclic graphs and VAR econometrics to simulate the upstream and downstream effects of imposition of an import quota: an application to u.s. wheat-related markets. Quantitative Methods for Assessing the Effects of Non-Tariff Measures and Trade Facilitation: 1, 193-214. https://doi.org/10.1142/5663

Dascal Dana. 2002. An analysis of EU wine trade: A gravity model approach. International Advances in Economic Research: 8(2), 135-147. https://doi.org/10.1007/BF02295344

Distance. 2019. Distance calculation. Available online: http://www.distancefromto.net/ (accessed on 1 December 2019).

FAO. 2019 Official website of the Faostat. Available online: http://faostat3.fao.org/home/E. (accessed on 1 December 2019).

Ferrantino Michael.2004.The Effects of Non-Tariff Measures on Prices, Trade, and Welfare: CGE Implementation of Policy-Based Price Comparisons. SSRN Electronic Journal: 2, 4-69. https://doi.org/10.2139/ssrn.539705 
Kang, H. 2006. International trade, OECD membership, and religion. Open Economies Review: 17(4), 493-508. https://doi.org/10.1007/s11079-006-0361-y

Keith Walsh.2006. Trade in Services: Does Gravity Hold? A Gravity Model Approach to Estimating Barriers to Services Trade. The institute for International Integration studies: 1, 183-204. https://doi.org/ 10.2139/ssrn.945335

Koo W. Won. 1994. A Gravity Model Analysis of Meat Trade Policies. Agricultural Economics: 10, 81-88. https://doi.org/10.1016/0169-5150(94)90042-6

Mirzobobo Yormirzoev. 2018. Food quality vs food patriotism Russian consumers' preferences for cheese after the food import ban. British Food Journal. 1(11), 371-385. https://doi.org/10.1108/BFJ-02-2018-0088

Rosstat. 2019. Russian federal state statistic service. Available online: https://eng.gks.ru/ (accessed on 1 December 2019).

Smutka Lubos, Spicka Jindrich., Ishchukova Natalia,. and Selby Richard. 2016. Agrarian import ban and its impact on the Russian and European Union agrarian trade performance. Agricultural Economics: 62(11), 493-506, DOI https://doi.org/10.17221/294/2015-AGRICECON

Timbergen Jan. 1962.Shaping the World Economy: Suggestions for an International Economic Policy. New York: The Twentieth Century Fund.

Uncomtrade. 2019. Un Comtrade database. Available online: http://comtrade.un.org/ (accessed on 1 December 2019).

Ward H. Joe. 1963. Hierarchical Grouping to Optimize an Objective Function. Journal of the American Statistical Association: 58(301), 236-244. https://doi.org/10.1080/01621459.1963.10500845

WTO. 2019 World Trade Organization statistics. Available online: https://www.wto.org/english/res_e/statis_e/world_commodity_profiles14_e.pdf, (accessed on 1 December 2019). 